\title{
THE EFFECT OF NON-ROUTINE GEOMETRY PROBLEM ON ELEMENTARY STUDENTS BELIEF IN MATHEMATICS: A CASE STUDY
}

\author{
Khoerul Umam ${ }^{1)}$, Kowiyah ${ }^{2)}$ \\ ${ }^{1)}$ Universitas Muhammadiyah Prof. DR. HAMKA, Jakarta, Indonesia \\ E-mail:khoerul.umam@uhamka.ac.id \\ ${ }^{2)}$ Universitas Muhammadiyah Prof. DR. HAMKA, Jakarta, Indonesia \\ E-mail: kowi_agil@yahoo.co.id
}

\begin{abstract}
Many learners hold traditional beliefs about perimeter and area that a shape with a larger area must have a larger perimeter while shape with the same perimeter must have the same area. To address this issue, non-routine geometry problem is given. This qualitative descriptive research used to reach the goal and to explore the effect of nonroutine geometry problem on elementary student belief in mathematics. The instrument has been developed to accommodate intuitive student belief and student's belief about the concept of perimeter. The results provide evidence that students' intuitive belief about perimeter can be change through non-routine geometry problem which is required understanding and some mathematical analysis. Fortunately, the problem has helped the elementary students revise and correct their beliefs, thoughts, and understandings relating to the circumference of shape.
\end{abstract}

Keywords: Geometry; Belief; Non-Routine Problem

\section{INTRODUCTION}

Elementary students face many difficulties in solving geometry problem including perimeter, and area $[1,15,16]$. In solving activity, students usually do not only use their mathematical content knowledge $[15,17,16]$ but also their belief in mathematics [18]. Mathematical content knowledge and belief in mathematics have a strong connection one to another because they have a positive relationship with them. Sometimes one factor can strengthen one another or conversely[20]. The influence of students' beliefs related to learning mathematics has been well researched. Although some beliefs in mathematics encourage learning, motivation, and performance, others have a negative impact may decrease their interest in mathematics so that some students always hinder to learn mathematics.

Many researchers $[19,5,6]$ from various subject have studied the effects of various beliefs on school subjects and have published their findings in many international educational journals. In response to the important role of belief in mathematics, teachers, educators, and researchers have developed and modified several mathematical instruments and provided various courses either formal or informal with the main goal to promote leading beliefs and correct the often observed traditional beliefs that interfere the process of learning mathematics at some level[12]. For example, students who believed that a shape with a larger area must have a larger perimeter while shape with the same perimeter must have the same area may lead to failure in solving unusual geometry problems. Many researchers like [2], [5], and [7] have given us many good examples of the interventions that assist their students to divert their traditional beliefs to leading belief.

This study intended to look into the effects of " nonroutine geometry problem", in challenging beliefs about misunderstanding student's belief on area and perimeter. For this purpose, non-routine geometry problems are used as sources of conceptual development of belief in mathematics[3]. The geometry problem chosen as exemplified by some well-known problems was made to show that the problem is capable of producing cognitive conflict, thereby challenging several traditional beliefs and helping elementary student correct his belief about perimeter. Consequently, the geometry problem was carried out to study how it helped participants to (a) explore the student's intuitive belief in the relationship between 
conceptual understanding of perimeter, and (b) assess and correct their beliefs in perimeter from different shapes. For this purpose, the subject was exposed to problem-solving and reflective writing activities capable of encouraging cognitive conflict leading to correcting traditional beliefs about perimeter.

\section{RESEARCH METHOD}

Research in mathematics education has shown the evidence that some learners are still held beliefs in a shape with a larger area must have a larger perimeter while shape with the same perimeter must have the same area. Hence, the goal of this case study was to look into the effects of a nonroutine geometry problem in helping elementary student shift their beliefs from misunderstanding the relationship about perimeter to correct belief. The research questions were as follows: How would the "non-routine geometry problem', affect elementary student's beliefs related to perimeter conceptual?

The design of this study took into account the difficulty of reaching the meanings of beliefs and the need to break the vicious circle of the relationship between beliefs, thought, and action [2],[19]. Therefore, we used interviews for the case study, allowing the students to explain their beliefs within a context [7]. Intuitive student's belief collected prior to problem-solving activity especially while students read a problem, and student's ability to revised his belief are collected after student solve the problem which required mathematical analysis[8],[10]. The participant is a student which is selected due to his speaking ability in explaining his answer. The subject was asked to compare the two objects with respect to another.

The problem-solving instruments are modified from [14] research by adding the square unit for constructing the different shapes. The modified instrument made to accommodate elementary student's intuitive belief and students confusion belief who remain believed that a shape with a larger area must have a larger perimeter while shape with the same perimeter must have the same area[14]. The instruments are as follows

There are 2 different figure formed by one unit square.

a. What is the circumference of each of different figures?

b. Are two different figures have a different circumference? Explain?

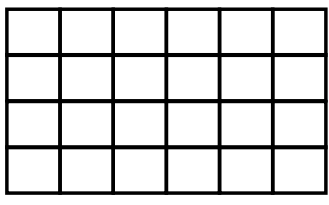

Figure 1

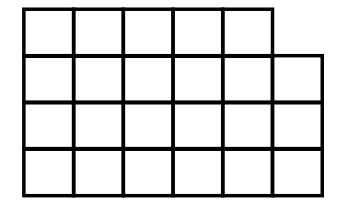

Figure 2
This research used qualitative analysis with deep interviewed. The format of interviewed was semi-structured and recorded for transcription, using the investigative questions to explore student's intuitive belief and how he can change his belief about perimeter. A respondent answered all questions with allotted time.

\section{RESULT AND DISCUSSION}

Our result will be discussed into two categories student belief in mathematics and raising students ability to correct his belief about perimeter. Data of deep interviewed between researcher $(\mathrm{R})$ and subject $(\mathrm{S})$ as follows:

A. Subject's Intuitive Belief in Mathematics

The results have shown us how student's intuitive belief strongly decided by his first sight on the different figures. Subject used his intuitive belief for determined his spontaneous decision without any mathematical knowledge analysis. He used his school experience to come up with his spontaneous response. Data as follows:

\begin{tabular}{|l|c|l|}
\hline $\mathrm{R}$ & $:$ & $\begin{array}{l}\text { Are two different figures have a different } \\
\text { circumference? }\end{array}$ \\
\hline $\mathrm{S}$ & $:$ & Yeah....different.... of course \\
\hline $\mathrm{R}$ & $:$ & Are you sure, these different? \\
\hline $\mathrm{S}$ & $:$ & sure...! \\
\hline $\mathrm{R}$ & $:$ & Why? \\
\hline $\mathrm{S}$ & $:$ & These shapes are different.... \\
\hline $\mathrm{R}$ & $:$ & Can explain it more details? \\
\hline $\mathrm{S}$ & $:$ & $\begin{array}{l}\text { Of course different...the first shape and the } \\
\text { second shape are different because they } \\
\text { have different types }\end{array}$ \\
\hline $\mathrm{R}$ & $:$ & Oh I see,... where is it? \\
\hline $\mathrm{S}$ & $:$ & $\begin{array}{l}\text { This is...different.... The second figure } \\
\text { has no one unit of square. }\end{array}$ \\
\hline $\mathrm{R}$ & $:$ & Do you believe that is different? \\
\hline $\mathrm{S}$ & $:$ & $\begin{array}{l}\text { Of course, I believed it....it is so } \\
\text { clear ...... second figure has no one unit of } \\
\text { square. }\end{array}$ \\
\hline
\end{tabular}

In the beginning step, his intuitive belief still plays main factor for his spontaneous answer about the perimeter of figures given. Visually, he believed that the first and second figures are different, as the second figure has not one unit square while the first figure has a complete square. His intuitive belief influenced his spontaneous decision because he believes that different figures will make different perimeter as well. His intuitive decision is like other students and adults who believed that a shape with a larger area must have a larger perimeter while shape with the same perimeter must have the same area[14]. It showed us that his quick response was previously interpreted as resulting from a misunderstanding of the relationship between the concepts of area and perimeter that usually occur among our students and were regarded as alternative conception in geometry [3].

\begin{tabular}{|l|c|l|}
\hline $\mathrm{R}$ & $:$ & $\begin{array}{l}\text { If two shapes are different, are they } \\
\text { have different perimeter? }\end{array}$ \\
\hline $\mathrm{S}$ & $:$ & $\begin{array}{l}\text { Yeah...of course...different } \\
\text { shape,...different perimeter. }\end{array}$ \\
\hline $\mathrm{R}$ & $:$ & How can you believe that...? \\
\hline $\mathrm{S}$ & $:$ & Usually in school like that... different \\
\hline
\end{tabular}


shape will have different perimeter.

From the above conversation, data interview show us that his belief in mathematics is strongly influenced by his teacher. Additionally, his teacher usually gives a routine geometry problem so that students cannot evolve mathematical knowledge. His visual reasons tell us about two things; different shape and incomplete one unit square that the first shape has not one unit square compared to the second shape. From his belief, we figure out that his spontaneous belief influenced by his behavioral activities in a school so that we can explain that his school experience plays important things to construct his intuitive belief.

B. Raising Students Ability to Correct His Belief About Perimeter

An evidence was shown us that subject seeks to correct the beliefs associated with his spontaneous answer. We will divide the analysis into three aspects: how students complete the perimeter of the first figure, the second figure, and how the student can correct the false beliefs related to the concept of perimeter.

\section{Subject Solve The First Figure}

After accomplishing the perimeter of first shape carefully, we can see that student attempted to count gradually the outer side of the first shape. Student's work is as followed:

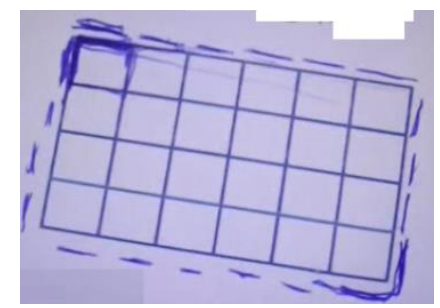

Fig. 1 Student's Answer for First Figure

In this activity, subject begins to solve the problem by counting gradually the outer side of the first shape. He also looks very confident in explaining his answer, because of he believes that a circumference is actually the sum of outer side around the first shape.

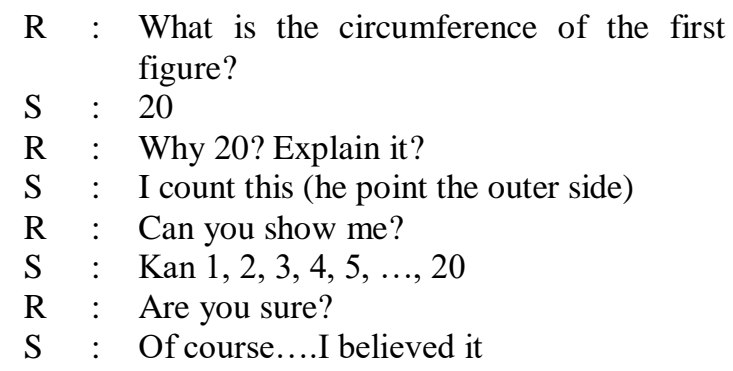

From the above interview, data has given an evidence that he counts one by one the outer side of the shape. He did not use the formula for solving this problem but he understands the definition of the circumference of shape. To ensure his understanding about circumference, we asked a provocative question to test him, the interview is as follows:

$\mathrm{R}$ : In your opinion, what is perimeter of shape?

$\mathrm{S}$ : If perimeter we count the outer side of shape.

$\mathrm{R}$ : Why the inner side, you do not count.

$\mathrm{S}$ : If I count inner sides, I count area not perimeter.

The results of the interview above, it appears that the subject believes that the circumference of shape is the actually the sum of outer side around the first shape. This reinforced his opinion that the inner sides lines of the first figure have nothing to do with the concept of the circumference, but the lines that are at the outer shape is closely related to the concept of the perimeter. This suggests that the subject not only can distinguish the concept of the circumference but also he can explain the concept of area.

\section{Subject Solve The Second Figure}

Subject use his analogical thinking to solve the second figure. He did not count anymore the perimeter of the second figure. He uses his analogical thinking about two kinds of line that can be moved from one to another position.

$\mathrm{R}$ : Figure 2?

$\mathrm{S}$ : 20 as well

$\mathrm{R}$ : Can you explain it?

$\mathrm{S}$ : If we close the cutting square. It will be like this. (the shape as follows)

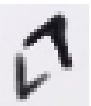

R : How can you do it....

$\mathrm{S}$ : Only made two lines.... like this

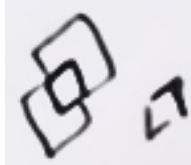

$\mathrm{R}$ : So, now, how about the perimeter of the second shape?

$\mathrm{S}$ : Yeah....the second shape has the same perimeter of the first shape

From the data, we can inference that two information made by subject. First, student's analogic has given an evidence that his analogical thinking relies on the comparison between two lines that relatively similar so that he can move two line either horizontal or vertical lines move to the outer side of second figures. After moving two lines, he assumed that the second figures and the first figure actually have similar circumferences, as a result, he did not count anymore to ensure his answers. Student's analogical reasoning plays a vital component in the process of abstraction through investigating some similarities of two different shapes [12].

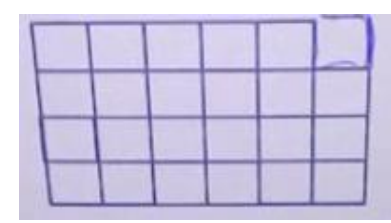




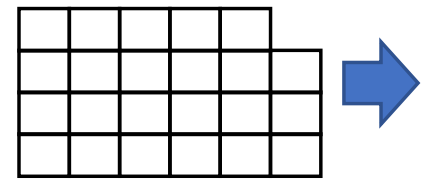

Fig. 2 Student's Work For A Perimeter of Second Shape

Second, data interview give a strong evidence that student unconsciously had emerged the concept of parallel line which actually he never studied before. The problem allows him to expand his mathematical knowledge. Data and interviewed has shown us that student can use analogical reasoning to regenerate new novel contexts [4].

3. Students Change His Belief About Perimeter

Several studies ([2],[7],[9]) have proven that belief in mathematics can be changed through several mathematical activities either formal or informal. Formal activities form a structured and strategic action usually use a classroom for their activities while informal activity can be formed in many kinds of activities. The conversation as follows shows us that students' belief

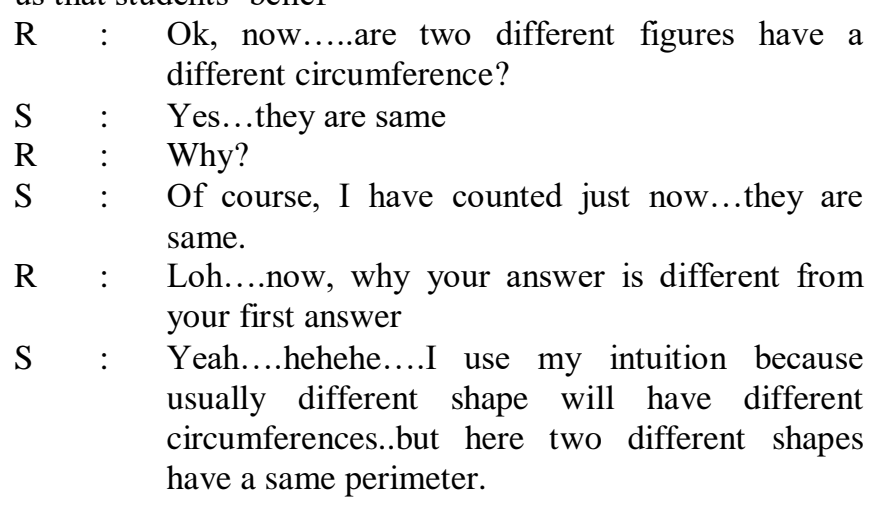

To ensure that student's belief has changed, we asked the same question and asked him to conclude his two different answers.
$\mathrm{R}$ : From your first and last answer. What can you conclude?
S : It means that different shapes perhaps will have the same circumferences

After subject solves the given problem, he changed his belief about the concept of perimeter. His spontaneous belief about perimeter is changed from a shape with a larger area must have a larger perimeter while shape with the same perimeter must have the same area to new belief about perimeter that is a shape with larger area in some cases will have the same perimeter.

\section{CONCLUSION}

Qualitative analysis from this studies suggests two conclusions. The first conclusion is student's intuitive belief closely related to school experiences. An evidence has shown us that his spontaneous belief is made from behavioral activity in a class. This belief constructed from his behavioral activity especially if student rarely gets the non-routine geometry problem so that he believed that different shape must have different perimeter. This result in line with [13] research shows that student's intuitive belief is an accumulating from behavioral activity in a school.

The second conclusion is non-routine geometry problem may have a considerable impact in shifting student's belief about perimeter. Our finding during the problem-solving activity that led us to conclude that the non-routine geometry problem activity as extracted from perimeter concept stimulated cognitive conflict help elementary student to positively affect his confusion belief about perimeter concept. Additionally, [11], and [7] asserted that the non-routine geometry problem can regenerate student's belief and view especially toward mathematics. With non-routine geometry, student can consciously revise his belief by doing several activities such as analyzing problems many times, recalling the definition of perimeter, and gradually counting the outer side of two different shapes.

\section{ACKNOWLEDGMENT}

This research project was funded by Lembaga Pengelola Dana Pendidikan (LPDP), Finance Minister of Indonesia Republic, and Research Grant from University of Muhammadiyah Prof DR HAMKA, Jakarta Number: 138 / F.03.07 / 2017.

\section{REFERENCES}

Alim, E. S., Rohim, S., \& Umam, K. 2015.Integration of Reciprocal Teaching-ICT Model to Improve Students' Mathematics Critical Thinking Ability'. In Proceedings of the 23rd International Conference on Computers in Education (ICCE 2015), Hangzhou, China (pp. 483-487).

Beswick, K. 2007. Influencing teachers' beliefs about teaching mathematics for numeracy to students with mathematics learning difficulties. Mathematics teacher Education and Development, 9, 3-20.

Dembo, Y., Levin, I., \& Siegler, R. S. 1997. A Comparison of The Geometric Reasoning of Students Attending Israeli Ultraorthodox and Mainstream Schools. Developmental Psychology, 33, 92-103.

Holyoak, K. J., \& Thagard, P. (1989). Analogical Mapping by Constraint Satisfaction. Cognitive Science, 13,295-355.

Hart, L. C. 2002. Pre-service teachers' beliefs and Practices After Participating in An Integrated Content/Method Course. School Science and Mathematics, 102(1), 4 14. 
Katz, V. 2000. Using History to Teach Mathematics: An International Perspective. Washington, DC: The Mathematical Association of America.

Kloosterman, P. 2002. Beliefs about Mathematics and Mathematics Learning in The Secondary School: Measurement and Implications For Motivation. In G. C. Leder, E. Pehkonen, \& G. Torner (Eds.), Beliefs: A hidden variable in mathematics education? (pp. 1337). Norwell, MA: Kluwer.

National Council of Teachers of Mathematics. 2000. Principles and Standards For School Mathematics. Reston, VA: Author.

Nigus, Hailu, \& Abraham, Solomon. 2014. The Effect of An Historical Perspective on Prospective Teachers' Beliefs in Learning Mathematics. J Math Teacher Educ 17: Page 303-330.

Nurhayati, N. (2016). The Effectiveness of the Collaborative Learning Model on Trigonometry Topic of Senior High School Student Graduate X Using Open-ended Approach. JETL (Journal Of Education, Teaching and Learning), 1(1), 13-17.

Schoenfeld, A. H. 1992. Learning to Think Mathematically: Problem Solving, Metacognition, and Sense Making in Mathematics. In D. A. Grouws (Ed.), Handbook of research in mathematics education (pp. 334-370). New York: Macmillan Publishing.

Sriraman, B. 2004. Gifted Ninth Graders' Notions of Proof. Investigating Parallels in Approaches of Mathematically Gifted Students and Professional Mathematicians. Journal for the Education of the Gifted, 27(4), 267-292.

Tsamir, Pessia \& Tirosh, Dina. 2002. Beliefs: A Hidden Variable in Mathematics Education?. Kluwer Academic Publisher.

Stavy, R., \& Babai, R. (2010). Overcoming Intuitive Interference in Mathematics: Insights From
Behavioral, Brain Imaging, and Intervention Studies. ZDM - International Journal on Mathematics Education, 42(6), 621-633. https://doi.org/10.1007/s11858-010-0251-z

Umam, K., 2016. Pengaruh Menggunakan Software Macromedia Flash 8 Terhadap Hasil Belajar Matematika Siswa Kelas VIII. Jurnal Kalamatika, 1(1), pp.84-92.

Umam, K., 2014. Pemahaman Siswa Dalam Pemecahan Masalah Matematika Berdasarkan Gaya Belajar Divergen. Jurnal Inovasi Pendidikan Dasar,1(1), pp.84-94.

Umam, K., Purwanto, S. E., \& Aprilina, C. N. 2016. Penggunaan Model Problem Based Learning Dengan Bantuan Software Geogebra Untuk Meningkatkan Hasil Belajar Matematika Siswa. Prosiding Konferensi Nasional Pendidikan Matematika-VI Universitas Negeri Gorontalo. Page 187-199.

Umam, K., Suswandari, Asiah, N., Wibowo, I. T., \& Rohim, S. 2017.The Effect of Think-Pair-Share Cooperative Learning Model Assisted With ICT on Mathematical Problem Solving Ability among Junior High School Students. Workshop Proceedings of the 25th International Conference on Computers in Education (ICCE 2017). New Zealand: Asia-Pacific Society for Computers in Education, (Page 94-98).

Purnomo, Y.W., 2017. A Scale for Measuring Teachers' Mathematics-Related Beliefs: A Validity and Reliability Study. International Journal of Instruction, 10(2).

Permana, R., Sabirin, F., \& Feladi, V. (2016). EFFECT OF SELF EFFICACY AND PRIOR KNOWLEDGE ON STUDENTS'SKILLS. JETL (Journal Of Education, Teaching and Learning), 1(2), 76-81. 